\title{
What mathematics knowledge for teaching is used by a Grade 2 teacher when teaching counting
}

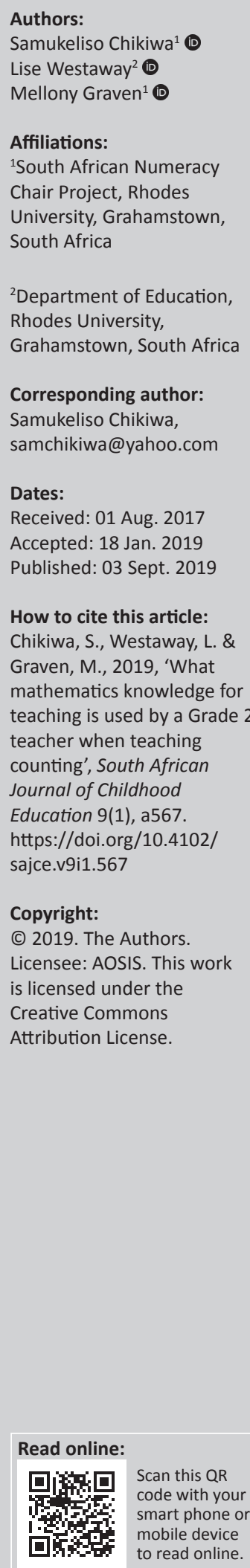

Background: The study on which this article is based investigated the Mathematics Knowledge for Teaching (MKfT) that a well experienced Grade 2 teacher utilized when teaching counting.

Aim: In this paper we share excerpts from one of the lessons of this Grade 2 teacher, which we analyzed to illuminate the various domains of MKfT and their interconnectedness in the teaching of counting.

Setting: The research was conducted in a former Model C school in the Eastern Cape province of South Africa.

Method: Using a case study methodology, 15 Grade 2 mathematics lessons were observed, video recorded and transcribed. Two formal interviews based on two selected video-recorded lessons were conducted to understand this teacher's practice. The data were analysed using Deborah Ball and colleagues' MKfT framework.

Results: The study found that Foundation Phase mathematics teaching requires the knowledge and tactful employment of all six knowledge domains as described in the work of Ball and colleagues. The Knowledge of Content and Teaching (KCT) domain, was found to be essential in teaching counting in Grade 2. The other five domains supported and informed the KCT domain.

Conclusion: We suggest from the insights gained here that research examining the MKfT that competent teachers draw on in teaching Foundation Phase mathematics could assist in developing curricula for in-service and pre-service teacher education programs.

Keywords: Mathematical Knowledge for Teaching; Counting; Number Sense; Mathematics Teaching; Pedagogical Content Knowledge; Teacher Knowledge.

\section{Background}

Poor performance in mathematics in South Africa is well documented and has been an area of concern for the past two decades (Bansilal, Brijlall \& Mkhwananzi 2014; Fleisch 2008; Kazima, Pillay \& Adler 2008; McAuliffe \& Lubben 2013; Reddy 2006; Spaull 2013). Studies that attempt to explain why South African learners are not performing competently in mathematics propose that many mathematics teachers in South Africa lack both content and pedagogical knowledge to teach mathematics. As such, learners acquire learning deficits early on in their schooling career that impact learner performance in their later years of schooling (Fleisch 2008; Graven 2016; Taylor \& Taylor 2013). Taylor (2011) suggests that interventions in mathematics education must first address these deficits to successfully raise learners' mathematical proficiency. Ball, Thames and Phelps (2008:395) propose that doing an analysis of teachers' practices and 'asking expert mathematicians and mathematics educators to identify the core mathematical ideas and skills that teachers should have' may be useful to ascertain what knowledge is required for the effective teaching of mathematics. This article is based on the first author's Master of Education research study that sought to understand the Mathematics Knowledge for Teaching (MKfT) as proposed by Ball et al. (2008) employed by a competent teacher of Foundation Phase (FP) mathematics to develop number sense through counting activities. The article aims to share the knowledge and skills this experienced Grade 2 teacher employed in her teaching. The MKfT framework was used as an analytical tool to two counting-related activities.

\section{Reasons underpinning teachers' deficit in knowledge for teaching mathematics}

Although poor learner performance in mathematics is often attributed to teachers' insufficient content knowledge and poor pedagogical practices, Carnoy et al. (2008) argue that the majority of these teachers have teaching qualifications. This suggests a discrepancy in the initial teacher education programmes. Teachers might not be adequately equipped to meet the demands of 
teaching during initial teacher education (Department of Basic Education [DBE] 2009). Research suggests a number of reasons behind teachers' poor MKfT (Adler 2005; Carnoy et al. 2008; DBE 2009).

Adler and Davis (2006) argue that teacher educators face challenges in embracing the content and pedagogical knowledge necessary for teaching mathematics under the legacy of apartheid. They argue that most students who enrol for initial teacher education programmes have limited mathematics content knowledge, resulting from being exposed to poor teaching by inadequately qualified teachers (Department of Education [DoE] 2004). The DoE (2004) argues that if these students become teachers, when they have not received adequate training that equips them with both content and pedagogical knowledge, they may continue to perpetuate poor teaching practices, leading to a revolving cycle of poor achievement. It is therefore necessary that teacher education programmes facilitate an end to this deficit cycle by incorporating programmes that would enhance the preservice and in-service teachers' mathematical content and pedagogical practices. However, Adler (2005) points out three challenges that teacher educators face regarding educating competent mathematics teachers. Firstly, she claims there is not enough knowledge about what is needed to prepare teachers for mathematics teaching and therefore urges that research should be conducted into the MKfT to inform teacher education programmes. This study responds to this call. Secondly, she maintains that there is a lack of ongoing support that enables mathematics teachers to be effective after they leave the university. Thirdly, she points out that universities are challenged to provide a large number of adequately and appropriately trained mathematics teachers at a time when there are fewer people who are taking up advanced study of mathematics and very few people choosing teaching as a profession. However, despite all these challenges teacher education still needs to work towards ending the cycle of poor teaching and poor learner achievement.

\section{Ball's conceptualisation of mathematics knowledge for teaching}

The DBE's (2009) assertion that teacher education is to blame for teachers' lack of both content knowledge and pedagogy concurs with what Shulman (1987) proposed four decades ago. He suggested that there was an imbalance in teacher education programmes as they focused either on pedagogy or on content, but never the two at the same time. Shulman (1986, 1987) endeavoured to bridge this dichotomy by introducing a special domain of teacher knowledge, which he referred to as Pedagogical Content Knowledge (PCK). He defined this knowledge as 'the ways of representing and formulating the subject, making it comprehensible to others' (Shulman 1986:9).

In analysing the demands of mathematics teaching, there is a need to identify both the Subject Matter Knowledge (SMK) and PCK that are required in the work mathematics teachers do. This is possible through studying and identifying the knowledge and skills utilised in the regular day-to-day demands of teaching (Chikiwa 2017). Ball et al. (2008:395) propose that analysing the work of teachers, where one observes teachers carrying out the work of teaching, and 'asking expert mathematicians and mathematics educators to identify the core mathematical ideas and skills that teachers should have', may be useful to ascertain what knowledge is required for the effective teaching of mathematics. Building on Shulman's (1986) notion of PCK, Hill, Rowan and Ball (2005) conducted an interactive work session to investigate the content and pedagogical knowledge and skills that are needed in the teaching of mathematics. Focusing on teachers' mathematics teaching practices, they managed to identify six knowledge domains. Together these six domains are referred to as MKfT. This framework has become influential in mathematics education because of its practice-based nature. Like Shulman's (1987) PCK, MKfT seeks to formulate and represent mathematics, 'making it comprehensible to others' (Shulman 1986:9). This suggests that teachers need to have a regular tendency of solving mathematical problems accurately, have reasons why they solve them that way and have different ways of doing so. They also need to know various ways of teaching each of the mathematical concepts in ways that are understandable to learners. MKfT is described as mathematical knowledge skills and habits of mind entailed in the work of teaching (Hill et al. 2005; Kim 2013). Ball et al. (2008:395) concur that MKfT 'is concerned with the tasks involved in teaching and the mathematical demands of these tasks'.

Mathematics knowledge for teaching consists of six domains refined from Shulman's two knowledge categories, namely, SMK and PCK. These six knowledge domains are deemed to be essential in the teaching of mathematics. SMK comprises Common Content Knowledge (CCK), Horizontal Content Knowledge (HCK) and Specialised Content Knowledge (SCK), while PCK comprises Knowledge of Content and Students (KCS), Knowledge of Content and Teaching (KCT) and Knowledge of Content and Curriculum (KCC) (Ball et al. 2008). These are briefly explained in Table 1.

In this article, as stated earlier, we analyse the MKfT that an expert Grade 2 teacher employed to effectively develop children's number sense through counting activities. The article is building on an earlier paper that focused on

TABLE 1: An explanation of the mathematics knowledge for teaching domains.

\begin{tabular}{|c|c|c|}
\hline $\begin{array}{l}\text { PCK } \\
\text { category }\end{array}$ & $\begin{array}{l}\text { MKfT } \\
\text { domain }\end{array}$ & Brief explanation \\
\hline \multirow[t]{3}{*}{ SMK } & $\mathrm{CCK}$ & $\begin{array}{l}\text { The general knowledge of mathematical concepts and skills } \\
\text { that can be utilised by anybody in day-to-day life. }\end{array}$ \\
\hline & $\mathrm{HCK}$ & $\begin{array}{l}\text { The mathematical knowledge that spans across the } \\
\text { mathematics curriculum that helps the teacher to view } \\
\text { mathematics as a whole. }\end{array}$ \\
\hline & SCK & $\begin{array}{l}\text { The special knowledge that is specifically required for the work } \\
\text { of teaching, which Kim (2013) refers to as knowledge that } \\
\text { makes a teacher a teacher, distinct from other professionals. }\end{array}$ \\
\hline \multirow[t]{3}{*}{ PCK } & KCT & $\begin{array}{l}\text { The knowledge that combines knowledge of mathematics } \\
\text { content and knowledge of teaching. }\end{array}$ \\
\hline & KCS & $\begin{array}{l}\text { This pertains to the knowledge that combines knowledge } \\
\text { of mathematics content and knowledge of students. }\end{array}$ \\
\hline & $\mathrm{KCC}$ & $\begin{array}{l}\text { The knowledge of the curriculum content requirements and } \\
\text { the materials that can be used to teach the relevant content. }\end{array}$ \\
\hline
\end{tabular}

PCK, pedagogical content knowledge; CCK, common content knowledge; SCK, specialised content knowledge; HCK, horizonal content knowledge; KCS, knowledge of content and students; KCT, knowledge of content and teaching; KCC, knowledge of content and curriculum. 
how this expert teacher managed the challenges children have with the -ty and -teen numbers. This article, however, illuminates how the expert teacher managed the errors that children encounter when bridging the decuples, while counting forwards and counting backwards.

\section{Developing number sense through counting on and counting back}

While research has established that mathematics is poorly performed in South Africa allegedly because most teachers lack adequate content and pedagogy, it has also been noted that the trajectory of poor performance begins at FP because of poorly developed number sense (Graven 2016; Graven et al. 2013; Hoadley 2012; Schollar 2008). Graven (2016) argues that learners exit FP with inefficient arithmetic strategies and as a result fail to cope with the arithmetic demands of the higher grades. A study conducted in grades 3 and 4 by Graven and Heyd-Metzuyanim (2014) found that many learners have not yet developed the advanced skills expected at their grade levels for solving mathematical problems that are inculcated through development of number sense.

Number sense develops as mathematical knowledge in children. Graven et al. (2013) propose that number sense is more than just the ability to count, name, identify and write numbers. Rather, they argue that number sense includes having a sense of what numbers are, understanding their relationship to one another, being able to perform mental math calculations efficiently and effectively, and being able to use numbers in real-world situations. Reys, Lindquist and Smith (2007) concur that number sense refers to a person's general understanding of number and operations, along with the ability to use this understanding in flexible ways to make mathematical judgements and to develop useful strategies for solving complex problems. Number sense grows gradually over time by exploring numbers, visualising numbers in a variety of contexts and relating to numbers in different ways (Burns 2007). Counting is important because it mediates between intuitive knowledge about quantities and basic arithmetic. Marmasse, Bletsas and Marti (2000) claim that:

[C]ounting is an important exercise for children. It helps them explore the relationships between numbers. Reflecting on number ordinality and realizing that smaller numbers are included within bigger numbers helps them modify their problem-solving strategies. (p. 5)

Our research sought to understand what MKfT an expert teacher employed to develop number sense through counting.

In this article, counting refers to the process that intends to find the muchness of a set through following the 'how to count' principles as explained by Gelman and Gallistel (1978). That is, the one-one (one numeral assigned to one item of the set) principle, the stable order principle (the same order of numerals should be maintained in all counts) and the cardinal principle (the last number name said represents the number of items in a set). Counting assists in identifying 'the number of things in a set' (Sarnecka \& Carey 2008:663). The processes of counting on and counting back thus assist in identifying 'how many'.

The process of learning to count and understand numbers and their sequence is not an easy one (Baroody \& Wilkins 1999). Researchers suggest that during the early stages of learning to count, learners face challenges that are related to the structure of the number system (Fuson 1988; Gifford 2005; Reys et al. 2007). Specifically, in English, one has to count up to 20 before one can recognise a pattern in the counting word sequence. Gelman and Gallistel (1978) identified five principles that they claimed to be useful in helping young children in learning to count, which are now commonly known as the 'counting principles'. These include the stable order principle, one-to-one correspondence, cardinality principle, order irrelevance and the abstraction principle. As noted earlier, the first three of these principles are regarded by Clements and Sarama (2009) as the 'how to count' principles. In other words, they give guidance on how counting should be done. The latter two are identified as the 'what to count' principles.

As learners demonstrate their knowledge of counting, specifically with regard to cardinality across a variety of tasks and situations, they may encounter a number of challenges that indicate they are still developing an understanding of the counting process. Clements and Sarama (2014) suggest that there are several errors that appear common amongst learners as they develop their counting proficiency. These include omitting or repeating numbers, skipping an item and not including it in the counting sequence, assigning more than one number word to a single item or pointing to two or more items while saying one number word and giving the wrong number when asked how many there are in a set. Reys et al. (2007) propose that lack of understanding of place value contributes to the challenges learners encounter as they learn to count. They argue that place value is a foundational concept for understanding the number system and for developing procedures for multi-digit operations and therefore is basic for mathematics learning. Hiebert and Wearne (1992) claim that understanding place value is essential for building connections between the key ideas of place value, such as quantifying sets of objects by grouping by 10 and treating the groups as units. They further claim that sound understanding of place value is indicated by the extent to which learners can efficiently count large collections and confidently make, name, record, compare, order, sequence, count forwards and backwards in place value parts, and rename multi-digit numbers in terms of their parts. Thus, learners need to develop an in-depth understanding of place value to be able to understand the number system. Reys et al. (2007) propose that the lack of understanding of place value results in some counting errors. Table 2 shows some counting errors that Reys et al. (2007) affirm to be related to place value. Errors in bridging the decuples are part of such errors. This article focusses on what MKfT an expert teacher used to manage such counting errors, particularly in the context of counting 
TABLE 2: Counting errors related to place value.

\section{Concept or skill}

Counting

Bridging the decade

or hundred

\section{Reversing digits when} writing number symbols

Writing numbers that were read aloud

Source: Adapted from Reys, R.E., Lindquist, M.M. \& Smith, N.L., 2007, Helping children learn mathematics, John Wiley \& Sons, Hoboken, $\mathrm{N}$.

on activities when counting on the number of dots on a dice to a given number.

A richer and more detailed analysis of how a competent Grade 2 teacher used counting as a means to develop learners' number sense by addressing all these challenges can be found in Chikiwa (2017). However, this article centres on challenges learners face when transitioning from one decade to another when counting forwards or backwards. This is referred to as 'bridging the decuples', such as $28,29,30,31$ or $41,40,39$ and so on. The challenges associated with bridging the decuples and how the teacher helped her learners overcome them are deliberated in two parts. The first part focuses on bridging the tens while counting forwards and the second part focuses on bridging the tens while counting backwards. The knowledge and skills the teacher used are analysed using the MKfT framework.

\section{Methodology}

A qualitative case study approach was employed in this study. One conveniently selected expert teacher, whom we refer to as 'Gail' (pseudonym), was carefully chosen because of the expertise and her 38 years of experience in FP teaching. Her competence as a teacher of FP mathematics was confirmed by her being selected by the DoE to lead the local cluster of FP mathematics teachers, by her teacher union to run mathematics workshops in the province and for her involvement in teaching FP mathematics methodology courses to preservice and in-service teachers at a local university.

Fifteen counting lessons were observed over 4 weeks of February in Gail's classroom at a school in the Eastern Cape province after following ethical procedures for conducting research within the classroom and school where she teaches. The lessons, together with two semi-structured interviews, based on selected lessons, were video recorded, transcribed and analysed using the MKfT framework. We share our analysis of a few excerpts from her lesson, specifically the counting and counting-related components of her lessons.

\section{Data presentation, analysis and discussion}

It is $33 \mathrm{~min}$ into the mathematics lesson and $7 \mathrm{~min}$ into the counting activity that Gail conducted on the carpet with the Brown Group. The Brown Group was composed of eight learners she deemed to be less mathematically competent. Gail and the Brown Group learners were playing a dice game where the first player rolls a dice and identifies the number of dots in the dice (e.g. 4). The learner counts on from a given number (e.g. 32) he reaches the final count (i.e. 36). The next player rolls the dice and counts on from the answer to the previous player's count. The third player rolls the dice and counts on from the last players count. The excerpt in Figure 1

\begin{tabular}{|c|c|c|}
\hline 19. & $\mathrm{~T}$ & $\begin{array}{l}\text { Right, I am going to start on 29. (Rolls the dice and gets } \\
\text { a two.) 31. (Passes the dice to the next learner.) }\end{array}$ \\
\hline 20. & L1 & (Rolls the dice and gets six.) 32, 33, 34, 35, 36, 37. \\
\hline 21. & $T$ & We are on 37. \\
\hline 22. & $\mathrm{LL}$ & (One learner rolls the dice and gets one.) 38 . \\
\hline 23. & L2 & Why are you telling me? 38. \\
\hline 24. & $\mathrm{~T}$ & Good, pass the dice on. \\
\hline 25. & L3 & (Rolls the dice and gets six but is stuck.) \\
\hline 26. & $\mathrm{~T}$ & What comes after 38 ? \\
\hline 27. & L3 & (Mumbles.) \\
\hline 28. & $T$ & $\begin{array}{l}\text { What is the next number after } 38 \text { ? (Flipping one finger } \\
\text { up at a time.) }\end{array}$ \\
\hline 29. & L3 & 39. (Silence.) \\
\hline 30. & $T$ & What number comes after 39 ? \\
\hline 31. & L3 & $\begin{array}{l}\text { 39. (Long silence, flipping fingers like trying to count } \\
\text { them.) } 39,40,41,42,43,44 \text {. }\end{array}$ \\
\hline 32. & $T$ & $\begin{array}{l}\text { No. } 41,42,43 \text {. (Counting on her fingers.) Come on! I want } \\
\text { you to practise. (Passing the dice to the next learner.) }\end{array}$ \\
\hline 33. & L4 & (Rolls and gets five.) 43. \\
\hline 34. & $\mathrm{~T}$ & No, you must not count 43 . Next number after 43 ? \\
\hline 35. & L4 & 44. \\
\hline 36. & $\mathrm{~T}$ & Good. (Passes the dice to the next learner.) \\
\hline 37. & L5 & (Rolls and get four.) 45, 46, 47, 48 . \\
\hline 38. & $T$ & $\begin{array}{l}\text { Good. (Raising her hand for a high five.) Well done! } \\
\text { What are we on? }\end{array}$ \\
\hline 39. & L5 & 48. \\
\hline 40. & $\mathrm{~T}$ & 48. (Passing the dice to the next learner.) \\
\hline 41. & L6 & (Rolls and gets two. Silence.) 48. (Counting his fingers.) \\
\hline 42. & $\mathrm{~T}$ & We don't count 48. Next number after $48 ?$ \\
\hline 43. & L6 & 49. 49. \\
\hline 44. & $\mathrm{~T}$ & After 49 ? \\
\hline 45. & L6 & (Silence.) 50. \\
\hline 46. & $\mathrm{~T}$ & Good. (Passes the dice to the next learner.) \\
\hline 47. & L7 & $51,52,53,54,55,56$. (Passes the dice to the next learner.) \\
\hline 48. & $\mathrm{~T}$ & Good. We want to hear, we are on 56. \\
\hline 49. & L8 & (Rolls the dice and gets a six.) 56. \\
\hline 50. & $\mathrm{~T}$ & We finished with 56 now, you see? \\
\hline 51. & LL & 57, 58. (Passes the dice to the next learner.) \\
\hline 52. & L8 & $\begin{array}{l}\text { Why is everybody telling me? (Rolls the dice and gets five. } \\
\text { Moves fingers in attempt to count.) }\end{array}$ \\
\hline 53 & TL8 & $\begin{array}{l}\text { (Teacher flicking his fingers in attempt to help the learner } \\
\text { to count.) } 59,60,61,62,63,64 \text {. }\end{array}$ \\
\hline $55-72$. & & $\begin{array}{l}\text { (Passes the dice to the next learner.) } \\
\text { (The activity continues.) }\end{array}$ \\
\hline 73. & L5 & (Rolls a two.) 76, 77. \\
\hline 74. & $\mathrm{~T}$ & Well done, Dan! (Passes the dice to the next learner.) \\
\hline 75. & L6 & (Rolls a three.) 78, 79, 76. \\
\hline 76. & $\mathrm{~T}$ & No! What comes after $79 ?$ \\
\hline 77. & L7 & $\begin{array}{l}\text { (Silence. The teacher points at three of the learner's } \\
\text { fingers, one at a time.) }\end{array}$ \\
\hline 78. & $T$ & What comes after 79 ? \\
\hline 79. & L7 & (Silence.) \\
\hline 80. & $\mathrm{~T}$ & 80. \\
\hline 81. & L7 & $80,81,82$ \\
\hline 82. & $T$ & Good! 82 \\
\hline
\end{tabular}

Source: Chikiwa, S., 2017, Investigating mathematical knowledge for teaching required to develop grade 2 learners' number sense through counting, viewed n.d., from https://www. ru.ac.za/media/rhodesuniversity/content/sanc/documents/Chikiwa\%20Masters\%20thesis. pdf; https://www.ru.ac.za/media/rhodesuniversity/.../Chikiwa\%20Masters\%20thesis.

FIGURE 1: Excerpt showing the challenges learners face in bridging the decades. T, Teacher; L, learner; LL, learners; TL1, teacher and Learner 1. 
begins with the teacher assuming a cumulative count of 29 . The game intends to help learners to master the counting sequence and to use counting on as a strategy for addition calculations. In this game, learners seemed to struggle with counting past the ninth digit of each decade. The excerpt in Figure 1 reflects one example of a learner who experienced a challenge in bridging the decuple.

Failing to bridge the decuples is common with young learners (Gifford 2005; Wright 2012). Prior to this lesson, Gail explained that the learners 'really battle to come out of one ten and get into the next one' (FI2, V1, T116). In the excerpt in Figure 1, Learner 3 struggled to count from 39, Learner 4 from 49 to 50, Learner 1 from 59 to 60 and Learner 7 from 79 to 80 . Once Gail realised the learners were having difficulty bridging the decuple, she counted with them or encouraged them to use their fingers. Each time the learners reached the ninth term of each decade they would get stuck. Gail knew the learners were stumped as a long silence followed while the learner tried to figure out what number should follow. She probed by asking, 'What number comes next?' The learners managed to bridge the decuple once they had been given time to think about it. However, with the transition from 79 to 80 Gail had to tell the Learner 7 the answer. Gail showed her expertise when teaching counting to her Brown Group by instructing them to play the dice game, which would facilitate rehearsal of forward counting in ones. Gail knew the challenges her learners had with forward counting and provided them with an interesting setting for practising their counting as they add on from the terminal number of the previous learner to new terminal number.

Counting the roll of the dice from the previous learner's count, Learner 6 in Turn 43 struggles to count on 2 from 48 . He counts to 49 but could not easily proceed to 50 . He had to think seriously before he could figure out that 50 follows 49 . Gail gave the learner adequate waiting time to think of the next number. This is crucial because during the process of counting, learners may need time to reorganise their thinking while going through a hurdle (Wright 2012). Wright (2012) also suggests that if learners seem not to remember the sequence, it is appropriate for the teacher to probe or give clues. Gifford (2005) and Wright (2012) acknowledge that the problem of failing to bridge the decuples is common with young learners. Gifford (2005) argues that it is appropriate for the teacher to tell the learners the next number in the counting sequence when they get stuck so that they do not completely lose their confidence. In the excerpt in Figure 1, Gail does not immediately tell the learners the numbers as Gifford suggests, rather she asks a question, points to their fingers, counts with them and extends the 'wait time', thus giving the learners time to think about the number that follows.

Gail's MKfT is evidenced in a number of ways in the excerpts related to bridging the decuple when counting forwards. She is able to anticipate what the learners experience as difficult when learning to count on and knows what they are likely to do (i.e. they keep quiet, have to think for an extended period or substitute an arbitrary number). This knowledge suggests that Gail knows about content and students and is able to combine the two in her teaching. In addition, she has specifically chosen a game to assist the learners in developing their ability to count on and bridge the decuples. Gail realises that the game is likely to capture her learners' attention and keep them focused on the purpose of the small group counting session. Her choice of the game also reflects her KCS. However, the use of the game to develop her learners' ability to count on and bridge the decuple also indicates that Gail values active learning and making learners develop a positive attitude towards mathematics by making learning mathematics fun. Furthermore, the dice provides an opportunity for children to point count if necessary and to support them in uttering one word for each dot on the dice. She claimed: 'Counting is not just a component of rote count, spit out of your mouth and it means absolutely nothing' (FI2, V2, T15). She explained that counting 'must be one to one; it must be an uttering the correct word on the correct number' (FI2, V2, T23).

\section{The bridging concept while counting back}

As discussed earlier, Reys et al. (2007) maintain that learners face challenges in bridging the decuples while counting forwards and backwards. The excerpt in Figure 2 highlights an example where Gail helped her learners to overcome the challenge of bridging the decuples while counting backwards. The excerpt in Figure 2 is taken from 15 min into the session, where Gail is counting with the whole class. The learners had been counting as a class in ones from 1 to 80 , while Gail was pulling beads across the bead-string. She moved away from the bead-string, sat on her chair next to the carpet and asked the learners to count back in ones again. This time she did not use the bead-string. Rather she asked the learners to 'close Mr Ten's house'. Closing of Mr Ten's house is a strategy where numbers are grouped in terms of tens. Each 10 is regarded as a 'house'. Numbers from 10 to 19 form Mr Ten's house, from 20 to 29 they are part of Mr Twenty's house and so forth. Because the learners are counting backwards in this activity, each house starts with the ninth term in the decade (e.g. 59 for Mr Fifty's house and 49 for Mr Forty's house).

The counting session in the excerpt in Figure 2 began with Gail telling her learners to 'close Mr Eighty's house', demonstrating with her hands. She closed Mr Eighty's house. The learners were familiar with this routine as they began to put their hands in the air to make the 'roof' of a house. Together with the learners, Gail closed Mr Eighty's house again. Gail asked the learners which ten's house they would 'fall' into, in other words, which decade is just below 80. The learners responded that they would 'fall' into Mr Seventy's house. Copying Gail, the learners raised their hands above their heads as they started counting back from the top of Mr Seventy's house, that is, from 79. Together with their teacher they counted back, moving their hands down (mimicking the sides of the house) as they counted. The end of each decade was announced through a 


\begin{tabular}{|c|c|c|}
\hline 34. & $\mathrm{~T}$ & Right we are on 80 now. (Sitting down.) Am I right? \\
\hline 35. & LL & Yes. \\
\hline 36. & $\mathrm{~T}$ & $\begin{array}{l}\text { So now we're gonna close Mr Eighty's house. Let's close } \\
\text { Mr Eighty's house (using her hands to show the shape of a } \\
\text { house starting with the roof). }\end{array}$ \\
\hline 37. & TLL & Close Mr Eighty's house. \\
\hline 38. & $\mathrm{~T}$ & Now we gonna fall into Mr who's house? \\
\hline 39. & LL & Mr Seventy's house. \\
\hline 40. & $\mathrm{~T}$ & $\begin{array}{l}\text { Mr Seventy's house where? (Using her hands to show the } \\
\text { shape of a house starting with the roof. Her hands are above } \\
\text { her head so that everyone can see.) }\end{array}$ \\
\hline 41. & LL & At the top. \\
\hline 42. & $T$ & Right, at the top, good. Let's go. \\
\hline 43. & TLL & 79, 78, 77. (Staggering their hands as they count down.) \\
\hline 44. & LL & $\begin{array}{l}\text { 76, 75, 74, 73, 72, 71. Close Mr Seventy's house. 69, 68, 67, } \\
66,65,64,63,62,61 \text {. Close Mr Sixty's house. }\end{array}$ \\
\hline 45. & $T$ & Good! We are where? \\
\hline 46. & TLL & $59,58, \ldots$ \\
\hline 47. & LL & $57,56,55,54,53,52,51$. Close Mr Fifty's house. \\
\hline 48. & $\mathrm{~T}$ & Good. \\
\hline 49. & LL & $\begin{array}{l}\text { 49, 48, 47, 46, 45, 44, 43, 42, 41. Close Mr Forty's house. 39, } \\
38,37,36,35,34,33,32,31 \text {. Close Mr Thirty's house. }\end{array}$ \\
\hline 50. & $\mathrm{~T}$ & Athi, where are we going to go now? \\
\hline 51. & $\mathrm{~L}$ & (Silent.) 29. \\
\hline 52. & $\mathrm{~T}$ & Athi says we fall on 29. Let's go, 29. \\
\hline 53. & LL & $29,28,27,26$ \\
\hline 54. & L & $\begin{array}{l}\text { (Teacher signals the class to keep quiet and points at one } \\
\text { learner who had seemingly not been attentive.) } 25,23 \text {. }\end{array}$ \\
\hline 55. & $T$ & Use your fingers. \\
\hline 56. & TLL & $\begin{array}{l}\text { (Pointing at the fingers as she counts down.) 25, 24, 23, 22, } \\
\text { 21. Close Mr Twenty's house. }\end{array}$ \\
\hline 57. & $\mathrm{~T}$ & Let's go on, 19. \\
\hline 58. & $\mathrm{LL}$ & $18,17,16,15,14,13,12,11$. Close Mr Ten's house. \\
\hline
\end{tabular}

Source: Chikiwa, S., 2017, Investigating mathematical knowledge for teaching required to develop grade 2 learners' number sense through counting, viewed n.d., from https://www. ru.ac.za/media/rhodesuniversity/content/sanc/documents/Chikiwa\%20Masters\%20thesis. pdf; https://www.ru.ac.za/media/rhodesuniversity/.../Chikiwa\%20Masters\%20thesis.

FIGURE 2: Excerpt showing the challenges learners face in bridging the decuples while counting back. T, Teacher; L, learner; LL, learners; TLL, teacher and learners.

'Close Mr Ten's house'. Once they said this, they knew they had reached a decuple and were crossing over to the next decade. Gail explained that the use of the expression and accompanying action assisted the learners in bridging the decuples.

The questions Gail asked her learners were used to guide them into being clear about the number before each decuple. She explained that she liked to do counting activities on the mat with the whole class, as there are some learners who are not confident counting backwards. She said that 'weak kids can learn from the stronger children' (FI2, V2, T39). Gail counted with the learners and then left them to count on their own. She reinforced their success in counting across each decuple with a verbal encouragement, a 'good', and kept on directing them with such questions as 'We are where?' to help them to keep focused.

Gail checked to see if individual learners were following and counting with the class. For example, she asked one of the learners, 'Athi, where are we going to go now?' When she noticed a learner was not focused on the task, she stopped the other learners and asked that learner to count on his own. This helped all the learners to be attentive and to participate in the counting activity. The learner who had to count on his own omitted a number as he counted down. Gail asked the learner to count with his fingers. To ensure that the learners knew what to do, she counted with him, pointing to her own fingers as they counted. The learners also stopped and started counting while pointing to their fingers. When they reached 20, they changed their action to close Mr Twenty's house. The learners were able to count smoothly down from 20 until they had closed Mr Ten's house.

Gail used this strategy to alleviate the challenges learners meet when counting backwards. As noted earlier, learners face greater challenges when counting backwards than when counting forwards, especially when bridging the decuple. Reys et al. (2007) attest that many learners find it difficult to count backwards, just as much as many adults find it difficult to recite the alphabet backwards. Use of such expressions as 'close Mr Seventy's house' seemingly has advantages of helping learners remember how these numbers are grouped into decades.

Gail guided the session through her questions. She asked her learners, 'After closing Mr Eighty's house, whose house do we fall into?' and 'Where do we fall?' This helped the learners to bridge the tens accurately, as the learners could imagine themselves having to go down from a multiple-storey building. Gail commented that 'closing the house' reminds them that:

$[W]$ e are now finished with Mr. Seventy's house. Otherwise what they will do is they will go to 70 again or they will go to 80 instead of going to sixty-nine. (Gail, 24 June 2016, personal interview)

Gail is echoing Wright's (2016) sentiments that in counting back learners can either fall into the wrong decuple or omit the decuple. Wright (2016) suggests that learners can face a number of challenges as they count backward, such as (1) counting down to the wrong decuple (e.g. 43, 42, 41, 30, $39,38)$ or (2) omitting the decuple $(43,42,41,39,38)$.

Gail had knowledge of and anticipated learner errors. She thus taught in a way that helped to avoid them. She was observant of what learners do as they count. She was able to identify learners who were committed to what they were doing and those who had lost the track. At Turn 52, Gail signals the class to keep quiet and points at one learner who had not been attentive. The learner misses the count and counts 'twenty-five, twenty-three', omitting 24. Gail used this as a way to keep all her learners actively and attentively involved in their learning because she stated that no learner would like to be put on the spot like that.

Gail realised that the learner mentioned above had lost focus because they had been counting in the same way all the way from 80 . She instructed the learners, 'Use your fingers' (L1, V1, T53), instead of staggering their hands down as they had been doing. Gail avoided being monotonous during her counting session as mentioned earlier, ' $[s] \mathrm{o}$ instead of just counting and being boring you need to throw in these other things to keep them focused' (FI2, V2, T37). When learners counted backwards to 10 , she stopped them, then further 
developed her counting session by connecting, counting backward, to taking away or subtraction. This is discussed further later in this chapter.

The excerpt in Figure 2 demonstrates Gail's employment of MKfT in her teaching. She is able to evaluate strategies that will work for different concepts she teaches. For example, she devised the 'close Mr Ten's house' strategy and notes that it can help learners to master not only crossing the decades but can be applied for crossing the hundreds and thousands as well. The same way it is used for the tens can apply to other levels of counting back. Her ability to evaluate procedures that work and are generalisable reflects her SCK, and putting these into practice requires her KCT. She employed her KCS to anticipate that her learners would find it quite challenging to count down across the decades and also that they would find it interesting and motivating to use the 'close Mr Ten's house' strategy.

Gail is able to sequence her lesson from the known to the unknown, from the simple to complex. Learners start by counting in ones, from 1 going up. All the learners were familiar with counting in ones, especially between 1 and 20 because they had been doing that since Grade 2. After counting forwards, she instructs them to count backwards. Gail demonstrates her KCC by keeping the counting within the range for Grade 2, counting numbers and facilitating both the forward counting and the backward counting. The DBE (2011) indicates that by the end of Grade 2 learners should be able to count forwards and backwards within the range of 200. Gail kept her range within 100, which is the minimum for Grade 1.

Gail also demonstrates her KCC through her knowledge of what resources learners can use for counting. She requested that her learners use their fingers in their counting. She stated that:

Well, our fingers are part of a resource. Yah, I mean your fingers can be ones, they can be twos, they can be fives, they can be one hundred, anything. (Gail, 24 June 2016, personal interview)

Gail encourages learners to use their fingers because fingers are 'part of them' (FI2, V2, T157). Her emphasis on using fingers is influenced by her understanding that:

[C]hildren need to learn; they need concrete objects in order to do maths. You can't just tell them something. Thus, the basis as well is you got to discover things using concrete apparatus. (wiggling her fingers) This is concrete. (Gail, 24 June 2016, personal interview)

She justified the use of fingers:

$[M] \mathrm{mhmm}$, it's much better for them to use their own fingers than to get up and walk around to go use your number grid; they can, but you're going to have lots of children walking around, whereas fingers are on your hands the whole time. (Gail, 24 June 2016, personal interview)

This also reflects that Gail is concerned about order in the learning environment. Table 3 summarises the aspects of each domain that were prevalent during the development of the concept of bridging the decuples while counting back.
TABLE 3: Summary of the mathematics knowledge for teaching domains prevalent in development of bridging the decuples concept while counting forwards and backwards.

\begin{tabular}{|c|c|}
\hline MKfT domains & Indicators \\
\hline SCK & $\begin{array}{l}\text { - Evaluate that the 'close Mr. Ten's house' strategy works for } \\
\text { counting back even across the hundreds or thousands and they } \\
\text { will always fall at the top of each 'house'. }\end{array}$ \\
\hline KCT & $\begin{array}{l}\text { - Remediate errors (e.g. when a learner counts back from } 71 \text { to } \\
60 \text {, she uses the flash cards to help the learner to realise that } \\
71 \text { count back one is } 70, \text { not } 60) \text {. } \\
\text { - Ask productive questions. The questions she asks learners about } \\
\text { which decade they fall into at the end of each decade and where } \\
\text { exactly they fall into help learners to be prepared to count back. } \\
\text { - Recognise what is involved in using a particular representation. } \\
\text { - Select appropriate representations to illustrate content. } \\
\text { - Sequence mathematical content and instruction. For example, } \\
\text { she instructs her learners to count back after they have counted } \\
\text { forwards. }\end{array}$ \\
\hline KCS & $\begin{array}{l}\text { - Anticipate what learners will find difficult or easy when counting } \\
\text { back, especially across the decades. She counts with them in } \\
\text { areas she anticipates to be challenging and leaves them to count } \\
\text { on their own where she anticipates they will find it easy. } \\
\text { - Predict what learners will find interesting and motivating when } \\
\text { choosing a representation. The 'close Mr. Ten's house' strategy } \\
\text { proved interesting and motivating to learners. } \\
\text { - Identify counting from } 71 \text { to } 60 \text { as a common error. } \\
\text { - Anticipate that learners may think that when they fall back into } \\
\text { the previous decade they start counting from where that house } \\
\text { begins and start counting forwards; for example, when they finish } \\
\text { the } 70 \text { s they fall into the } 60 \text { s and may count from } 60 \text { upwards. }\end{array}$ \\
\hline KCC & $\begin{array}{l}\text { - Articulate the expectations of the FP mathematics curriculum } \\
\text { (Grade } 2 \text { learners are expected to be able to count in ones } \\
\text { forwards and backwards between } 1 \text { and } 200) \text {. } \\
\text { - Articulate familiarity with the FP mathematics curriculum } \\
\text { (learners at Grade } 2 \text { are expected to do much counting). } \\
\text { - Demonstrate knowledge of what resources learners can use to } \\
\text { count (e.g. their fingers). } \\
\text { - Demonstrate knowledge of the topics in the Grade } 2 \text { curriculum } \\
\text { (e.g. counting and subtraction). }\end{array}$ \\
\hline HCK & $\begin{array}{l}\text { - Make connections between counting back and subtraction. } \\
\text { For example, when a learner is challenged to count back from } \\
71 \text {, she asks the learner to take away } 1 \text { from } 71 \text { to get the } \\
\text { number the learner needs to count back to. }\end{array}$ \\
\hline
\end{tabular}

Source: Chikiwa, S., 2017, Investigating mathematical knowledge for teaching required to develop grade 2 learners' number sense through counting, viewed n.d., from https://www. ru.ac.za/media/rhodesuniversity/content/sanc/documents/Chikiwa\%20Masters\%20thesis. pdf; https://www.ru.ac.za/media/rhodesuniversity/.../Chikiwa\%20Masters\%20thesis.

SCK, Specialised Content Knowledge; HCK, Horizontal Content Knowledge; KCS, Knowledge of Content and Students; KCT, Knowledge of Content and Teaching; KCC, Knowledge of Content and Curriculum.

These domains were measured through analysing Gail's words and actions against the indicators of each domain, as proposed by Hurrell (2013).

\section{Ethical considerations}

Gail voluntarily participated in this research. The name Gail is a pseudonym that was used to protect the teacher's identity.

\section{Key findings and conclusion}

In using the MKfT framework for analysing the data, the indicators provided by Ball et al. (2008) for each domain were not particularly useful in relation to the teaching of counting. This was especially notable when analysing Gail's SCK in relation to counting. Given this, we had to establish our own indicators by drawing on Ball et al.'s (2008) definitions of each of the domains.

In this study, we found that there is a strong interdependence between the MKfT domains. KCT, however, seemed to be the centre of MKfT. The study found KCT directly linked 
the teacher and the learner with the concept of counting. However, all the domains work together to enable the teacher to effectively present mathematical ideas in ways that learners will find meaningful. Gail's KCT, for example, is enriched by the experience Gail gains as she teaches. For example, for Gail to know that learners have challenges in bridging the decuples she would probably have experienced it a number of times during the counting lessons or learned it from someone or from a text. That knowledge would enable her to design teaching strategies and representations that would address the learners' problems. The learners would only benefit if Gail uses the strategies informed by her knowledge in her teaching. We thus suggest that the five domains (CCK, SCK, KCC, HCK and KCS) influence her KCT. Gail employs these five domains to carry out the work of teaching by presenting the content sequentially, making good use of the appropriately selected representations and examples, asking productive questions and so on. Thus, the other knowledge domains facilitated better teaching by informing the teacher what content to teach (KCC); how it related to the topics that have already been taught or are still to come (HCK); what misconceptions and errors are associated with the chosen content (KCS); and what principles underlay the teaching of the content (SCK). The teacher must then have an in-depth understanding of that content area so that he or she can accurately present it and evaluate the work she or he assigns to the learners (CCK). While not underestimating the value of the other domains in the work of teaching by foregrounding KCT, Figure 3 presents our understanding of how MKfT domains relate.

This analysis of Gail's teaching establishes the existence of these domains and illuminates their interrelationship. Throughout this research, Gail was not always conscious of

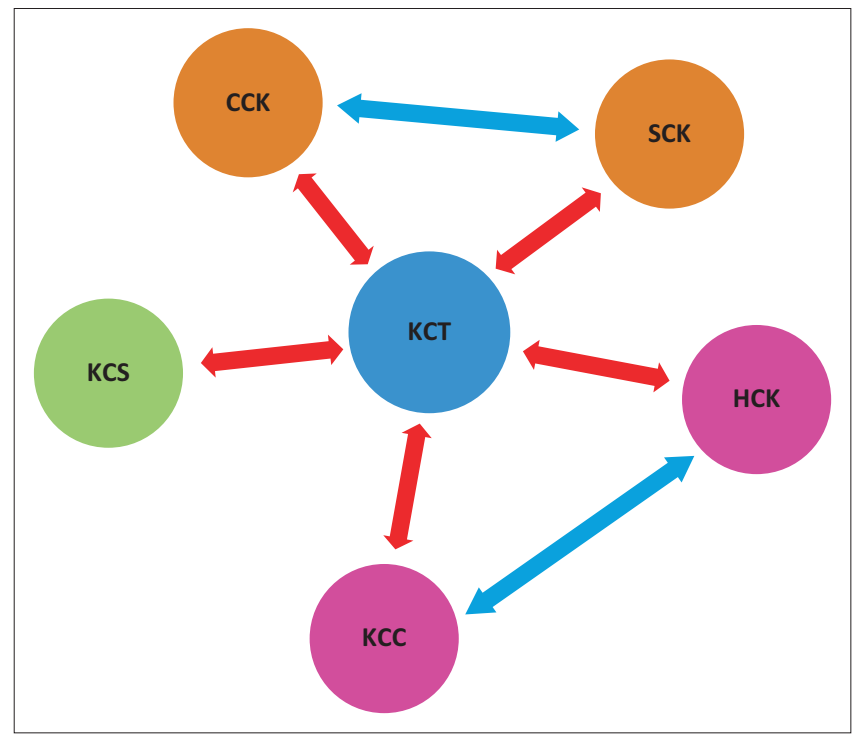

Source: Chikiwa, S., 2017, Investigating mathematical knowledge for teaching required to develop grade 2 learners' number sense through counting, viewed n.d., from https://www. ru.ac.za/media/rhodesuniversity/content/sanc/documents/Chikiwa\%20Masters\%20thesis. pdf; https://www.ru.ac.za/media/rhodesuniversity/.../Chikiwa\%20Masters\%20thesis.

FIGURE 3: How the mathematics knowledge for teaching domains relate to each other. SCK, Specialised content knowledge; KCT, knowledge of content and teaching; KCS, knowledge of content and students; KCC, knowledge of content and curriculum; HCK, horizonal content knowledge; CCK, common content knowledge. her MKfT. Her counting sessions were seamless and, in many respects, her MKfT was automated. Like an experienced driver, Gail did not stop to think about what MKfT she was drawing on at any particular moment in time.

We believe that the value of this research lies in the contribution to teacher education programmes. Knowing what knowledge a competent teacher draws on in developing children's number sense through counting has the potential to influence the design of mathematics methodology courses for both preservice and in-service teachers. Knowing, for example, the possible counting errors that children make in relation to place value would assist teachers in designing activities to pre-empt such errors. This is exactly what Gail did in her class.

\section{Acknowledgements}

This article is extracted from the first author's (S.C.) master's thesis. The authors extend their sincere thanks to the research participant, the reviewers and all who supported the authors as they worked on this study.

\section{Competing interests}

The authors declare that they have no financial or personal relationships that may have inappropriately influenced them in writing this article.

\section{Authors' contributions}

S.C. carried out the research, wrote the article under the guidance of both supervisors, worked on the reviewers' comments and submitted the finalised article. L.W. was the supervisor for the MEd thesis and M.G. was the co-supervisor. Both supervisors contributed to the article by advising S.C. and assisting with the edits.

\section{Funding information}

The research was funded by the National Research Foundation (NRF) under the Rhodes University South African Numeracy Chair.

\section{Data availability statement}

Data sharing is not applicable to this article as no new data were created or analysed in this study.

\section{Disclaimer}

The views and opinions expressed in this article are those of the authors and do not necessarily reflect the official policy or position of any affiliated agency of the authors.

\section{References}

Adler, J., 2005, 'Mathematics for teaching: What is it and why is it important that we talk about it?', Pythagoras 62, 2-11. https://doi.org/10.4102/pythagoras.v0i62.109

Adler, J. \& Davis, Z., 2006, 'Opening another black box: Researching mathematics for teaching in mathematics teacher education', Journal for Research in Mathematics Education 37(4), 270-296. 
Ball, D.L., Thames, M.H. \& Phelps, G., 2008, 'Content knowledge for teaching: What makes it special?', Journal of Teacher Education 59(5), 389.

Bansilal, S., Brijlall, D. \& Mkhwanazi, T.W., 2014, 'An exploration of the common content knowledge of high school mathematics teachers', Perspectives in Education 32(1), 3450.

Baroody, L.M. \& Wilkins, A.J., 1999, 'The development of informal counting, number and arithmetic skills and concepts', in J. Copley (ed.), Mathematics in the early years, birth to five, pp. 49-64, National Council of Teachers of Mathematics (NCTM), Reston.

Burns, M., 2007, About teaching mathematics: A k-8 resource, 3rd edn., Math Solutions, Sausalito, CA.

Carnoy, M. \& Chisholm, L., 2008, Towards understanding student academic performance in South Africa: A pilot study of grade 6 mathematics lessons in South Africa, HSRC Press, Pretoria.

Chikiwa, S., 2017, Investigating mathematical knowledge for teaching required to develop grade 2 learners' number sense through counting, (Unpublished master's thesis) Rhodes University, Grahamstown.

Clements, D. \& Sarama, J., 2009, Learning and teaching early math: The learning trajectories approach, Routledge, New York, NY.

Clements, D.H. \& Sarama, J., 2014, 'The importance of the early years', in R.E. Slavin (ed.), Science, technology \& mathematics (STEM), pp. 5-9, Corwin, Thousand Oaks, CA

Department of Basic Education, 2009, National examinations and assessment: Report on the national senior certificate examination results, part 2, Department of Basic Education, Pretoria.

Department of Basic Education, 2011, Curriculum and assessment policy statement Department of Basic Education, Pretoria.

Department of Education, 2004, Qualitative overview of the further education and training sector: A sector in transition, Department of Education, Pretoria.

Fleisch, B., 2008, Primary education in crisis: Why South African school-children underachieve in reading and mathematics, Juta, Johannesburg.

Fuson, K.C., 1988, Children's counting and concepts of number, Springer-Verlag, New York, NY.

Gelman, R. \& Gallistel, C., 1978, The child's understanding of number, Harvard University Press, Cambridge.

Gifford, S., 2005, Teaching mathematics 3-5: Developing learning in the foundation stage, Open University Press, Maidenhead.

Graven, M., 2016, 'When systemic interventions get in the way of localized mathematics reform', For the Learning of Mathematics 36(1), 8-13.

Graven, M. \& Heyd-Metzuyanim, E., 2014, 'Exploring the limitations and possibilities of researching mathematical dispositions of learners with low literacy levels', Scientiain Educatione 5(1), 20-35.

Graven, M., Venkat, H., Westaway, L. \& Tshesane, H., 2013, ‘Place value without number sense: Exploring the need for mental mathematical skills assessment within the Annual National Assessments', South African Journal of Childhood Education 3(2), 131-143. https://doi.org/10.4102/sajce.v3i2.45
Hiebert, J. \& Wearne, D., 1992, 'Links between teaching and learning place value with understanding in first grade', Journal for Research in Mathematics Education 23(2), 98-122. https://doi.org/10.2307/749496

Hill, H.C., Rowan, B. \& Ball, D.L., 2005, 'Effects of teachers' mathematical knowledge for teaching on student achievement', American Educational Research Journal 42(2), 371-406. https://doi.org/10.3102/00028312042002371

Hoadley, U., 2012, 'What do we know about teaching and learning in South African Primary schools?', Education as Change 16(2), 187-202. https://doi.org/10.1080/ 16823206.2012.745725

Kazima, M., Pillay, V. \& Adler, J., 2008, 'Mathematics for teaching: Observations from two case studies', South African Journal of Education 28(2), 283-299.

Kim, H., 2013, 'Towards teaching for developing students' mathematical reasoning: A case study on teaching formative assessment lessons', paper presented at the International Workshop on Mathematics Education, Seoul, Korea, July 26-28, 2013, n.p.

Marmasse, N., Bletsas, A. \& Marti, S., 2000, Numerical mechanisms and children's concept of numbers, viewed 02 April 2017, from http://web.media.mit.edu/.

McAuliffe, S. \& Lubben, F., 2013, 'Perspectives on pre-service teacher knowledge for teaching early Algebra', Perspectives in Education 31(3), 155-169.

Reddy, V., 2006, Mathematics and science achievement at South African schools in TIMSS, HSRC Press, Pretoria.

Reys, R.E., Lindquist, M.M. \& Smith, N.L., 2007, Helping children learn mathematics, John Wiley \& Sons, Hoboken, NJ.

Sarnecka, B.W. \& Carey, S., 2008, How counting represents number: What children must learn and when they learn it, Department of Cognitive Sciences, SSPA 3151, University of California, Irvine, CA.

Schollar, E., 2008, Final report: The primary mathematics research project: 2004-2007. Towards evidence-based educational development in South Africa, Eric Schollar and Associates c.c., Johannesburg.

Shulman, L.S., 1986, 'Those who understand: Knowledge growth in teaching', Educational Researcher 15(2), 4-14. https://doi.org/10.3102/0013189X015002004

Shulman, L.S., 1987, 'Knowledge and teaching: Foundations of the new reform', Harvard Educational Review 57(1), 1-23. https://doi.org/10.17763/haer.57.1. j463w79r56455411

Spaull, N., 2013, South Africa's education crisis, Centre for Development and Enterprise, Johannesburg.

Taylor, N. \& Taylor, S., 2013, 'Teacher knowledge and professional habitus', in N. Taylor, S. Van der Berg \& T. Mabogoane (eds.), Creating effective schools, pp. 202-232, Pearson, Johannesburg.

Taylor, S., 2011, Uncovering indicators of effective school management in South Africa using the National School Effectiveness Study, Stellenbosch Economic Working using the National School Effectiveness Study, Stellenbosch Econ
Papers No. 10/11, pp. 1-51, Stellenbosch University, Stellenbosch.

Wright, A., 2012, 'Tablets over textbooks', Communications of the ACM 55, viewed n.d., from https://www.scribd.com/document/234152582/tablets-overviewed n.d., from https

Wright, B., 2016, 'Assessing early numeracy', paper presented at Rhodes University, Grahamstown, 09 September 2016. 